\title{
Chadha and the Nondelegation Doctrine: Defining a Restricted Legislative Veto
}

The principle of absolute nondelegation, as first articulated by John Locke, holds that legislators, as agents of the people, may not delegate to others their legislative power. ${ }^{3}$ Strict construction of this principle would forbid the executive to exercise any part of the legislative power. The Framers of the Constitution rejected such a pure separation of the legislative and executive branches, however, requiring only that one branch of government not exercise the entire power of another. ${ }^{2}$ Consequently, when the Supreme Court gave the nondelegation principle practical effect during the New Deal era, the Court did not insist upon absolute nondelegation. ${ }^{3}$ Instead, the Court upheld a standards requirement, ${ }^{4}$ requiring only that Congress make primary policy choices and devise statutory standards $^{5}$ to guide subordinate policymaking in the executive branch. Since the New Deal, however, the Court has repeatedly refused to strike down standardless delegations, ${ }^{6}$ divesting even this compromise of Locke's absolute nondelegation principle of much practical significance. ${ }^{7}$

Encouraged by the Court's lax enforcement of the standards requirement, Congress has dramatically increased its delegations of policymaking

1. J. Locke, The Second Treatise of Government $\S 141$, in Two TREaTISES of Government 408-09 (P. Laslett ed. 1963) ("The power of the Legislative being derived from the People by a positive voluntary Grant and Institution, can be no other, than what that positive Grant conveyed, which being only to make Laws, and not to make Legislators, the Legislative can have no power to transfer their Authority of making Laws, and place it in other hands.").

2. See The Federalist No. 47 (J. Madison) (arguing that Gonstitution prohibits only exercise by one branch of whole power of another, but permits partial agency relationship between branches); The Federalist No. 48, at 308 (J. Madison) (C. Rossiter ed. 1961) ("[T] he powers properly belonging to one of the departments ought not to be directly and completely administered by either of the other departments.").

3. See A.L.A. Schechter Poultry Corp. v. United States, 295 U.S. 495, 530 (1935) (Congress may delegate limited power to determine facts and prescribe subordinate rules); Panama Ref. Co. v. Ryan, 293 U.S. 388, 421 (1935) (same).

4. See infra notes 18-29 and accompanying text.

5. A "standard," as used in this Note and generally in the literature on delegation, is a restriction upon the discretion that an administrative agency may exercise in implementing a statute. "Implementation" of a statute contemplates the making of secondary policy choices, the choice of situations to which a statute is to apply, and the choice of a mechanism for enforcing a statute.

6. See, e.g., Lichter v. United States, 334 U.S. 742, 778-86, reh'g denied sub nom. Pownall v. United States, 335 U.S. 836 (1948) (upholding Renegotiation Act, which authorized executive agencies to recover "excessive profits" from defense contractors, without defining term "excessive"); National Broadcasting Co. v. United States, 319 U.S. 190, 225-26 (1943) (upholding Federal Communications Act authorizing Federal Communications Commission to license radio stations in accord with "public interest").

7. Aranson, Gellhorn \& Robinson, A Theory of Legislative Delegation, 68 CoRnel. L. Rev. 1, 17 (1982) (nondelegation doctrine relegated to "fugitive existence" after New Deal) [hereinafter cited as Aranson]. 
authority to the executive branch-a practice greatly facilitated by use of the legislative veto provision. ${ }^{8}$ With its 1983 decision in Immigration and Naturalization Service v. Chadha, ${ }^{\circ}$ however, the Court struck down a one-House legislative veto, ${ }^{10}$ using a line of reasoning derived from the principle of absolute nondelegation. This Note argues that the Gourt should have been true to its earlier compromise of the nondelegation principle. Under the standards requirement, judicial enforcement of statutory standards that govern agency policymaking provided a workable substitute for the constitutional checks of presentment and bicameralism to which legislative lawmaking is subject. By analogizing to the standards requirement, the Court could have found these constitutional checks, the explicit concerns of the Chadha opinion, inapplicable, and approved a modified "affirmative" legislative veto ${ }^{11}$ restricted by judicial review. Such a veto

8. See infra text accompanying notes 44-45, 50-52. The legislative veto enabled Congress to approve or reject actions taken by administrative agencies esercising discretionary authority delegated by Congress. For more detailed descriptions of the legislative veto, see Cooper \& Cooper, The Legislative Veto and the Constitution, 30 GeO. WASH. L. REv. 467, 467-69 (1962); Javits \& Klein, Congressional Oversight and the Legislative Veto: A Constitutional Analysis, 52 N.Y.U. L. REv. 455, 456-58, 462-65 (1977).

9. 462 U.S. 919 (1983). Jagdish Chadha was a nonresident alien who, after overstaying his student visa, applied to the Immigration and Naturalization Service (INS) for suspension of his deportation. Section 244(a)(1) of the Immigration and Nationality Act, 8 U.S.C. $\S 1254$ (a)(1) (1982) provides that the Attorney General may, in his discretion, suspend deportation of an alien who has been physically present in the United States for a continuous period of not less than seven years, who proves that during all of such period he was and is a person of good moral character, and whose deportation would result in extreme hardship to the alien or to a spouse, parent or child who is a citizen or permanent resident. The Attorney General discharges his responsibilities under this provision through the Immigration and Naturalization Service, a division of the Department of Justice. See 8 U.S.C. $\S$ 1103(a) (1982).

Section 244(c)(2) of the Immigration and Nationality Act, 8 U.S.G. $\$ 1254(c)(2)$ (1982) provides that if either the Senate or the House of Representatives passes a resolution stating that it does not favor the suspension of an alien's deportation, the Attorney General shall deport the alien or authorize his voluntary departure at his own expense. If neither the Senate nor the House passes such a resolution, the Attorney General may cancel deportation proceedings. Id. After an immigration judge suspended Chadha's deportation, the House of Representatives, acting pursuant to this legislative veto provision, passed a resolution to veto the judge's decision. The House resolution was apparently prompted by the determination of the House Committee on the Judiciary that Chadha, together with five other aliens, did not meet the Act's hardship requirement. See 462 U.S. at 926-27.

Chadha responded to the House resolution by challenging the constitutionality of $\S 244$ (c)(2). Id. at 928. The Supreme Court, in a 7-2 decision, held this one-House veto unconstitutional by virtue of its failure to comply with the presentment and bicameralism requirements.

10. Depending upon the terms of the enabling legislation, both Houses of Congress, one House, or a congressional committee could exercise a legislative veto. (Under an affirmative veto provision, infra note 11, both Houses "exercise" the veto by failing to act; this might be termed a "no-House" veto.).

11. Two forms of the legislative veto were possible. Under the affirmative form, presidential or agency action took effect only upon passage of a resolution of approval, so that a veto was accomplished by congressional inaction. See Cooper \& Cooper, supra note 8, at 468. Examples of affirmative veto provisions are contained in the Export-Import Bank Amendments of 1974, 12 U.S.C. $\$ 635 e$ (1982) (Presidentially-proposed limitation on exports to Soviet Union in excess of $\$ 300$ million must be approved by concurrent resolution), and the Trade Expansion Act of 1962, 19 U.S.C. \$ 1981(a)(2) (1982) (tariff or duty recommended by International Trade Commission may be imposed by concurrent resolution of approval). 
would advance the goals that gave rise to the standards requirement; it could also resolve the problem which forced the Court to abandon the standards requirement after the New Deal, namely that Congress cannot prescribe appropriate standards for unforeseeable situations.

\section{Chadha AND THE Nondelegation DoctrINE}

The nondelegation principle derives its theoretical foundation from the rule of agency law that power transferred by a principal to an agent cannot be delegated in turn by the agent; such a redelegation would conflict with the purpose of the original transfer..$^{12}$ In the legislative context, this rule implies that congressional delegation of legislative power frustrates the intent of the people to entrust such power only to representatives whom they have chosen. ${ }^{13}$ Such delegation, moreover, permits lawmaking by parties not subject to constitutional requirements governing adoption of legislation-namely the election process, presentment, ${ }^{14}$ and bicameralism. ${ }^{16}$ Together these requirements ensure a sort of legislative due process without which the people would not have delegated lawmaking power to Congress. ${ }^{16}$

Interpreted strictly, the nondelegation doctrine would require Congress to make all policy determinations. Yet it is impractical to require that Congress predict each and every circumstance in which its policy must apply. Before Chadha, the Supreme Court never required either complete nondelegation of the legislative power, or the absolute separation of powers which would result. ${ }^{17}$ Instead, the Court sought at most to preserve

\footnotetext{
Under the negative form, agency action took effect after a specified period of time, unless vetoed by Congress with a resolution of disapproval. See Cooper \& Cooper, supra note 8, at 468 . Examples of negative veto provisions are contained in the Federal Trade Commission Improvements Act of 1980, 15 U.S.C. $\$$ 57a-1 (a) (1982) (FTC rules may be disapproved by concurrent resolution), and the Act of January 2, 1975, 28 U.S.C. $\$ 2076$ (1982) (Supreme Court's proposed amendments to Federal Rules of Evidence may be disapproved by resolution of either House). By whomever exercised and in either form-inaction or resolution-the legislative veto was as binding upon the affected agency as if enacted in legislation, and as enforceable in the federal courts. See Cooper \& Cooper, supra note 8, at 474.

12. See Aranson, supra note 7 , at 4 .

13. Id.

14. U.S. Const. art. I, $\S 7$, cls. 2,3 .

15. U.S. ConsT. art. I, § $1 \& \& 7$, cl. 2.

16. See Aranson, supra note 7 , at 4-5.

17. See, e.g., Buckley v. Valeo, 424 U.S. 1, 121 (1976) ("[T]he Constitution by no means contemplates total separation of each of these three essential branches of Government . . . . [A] hermetic sealing off of the three branches of Government from one another would preclude the establishment of a Nation capable of governing itself effectively."); Youngstown Sheet \& Tube Co. v. Sawyer, 343 U.S. 579, 635 (1952) (Jackson, J., concurring) ("[The Constitution] contemplates that practice will integrate the dispersed powers into a workable government. It enjoins upon its branches separateness but interdependence, autonomy but reciprocity."); see also THE FEDERALIST No. 47 (J. Madison) (arguing that three branches need not be wholly separate); cf. Chadha, 462 U.S. at 984 (White, J., dissenting) ("[L]egislative authority is routinely delegated to the Executive branch, to the independent regulatory agencies, and to private individuals and groups.").
} 
the nondelegation principle in spirit by enforcing the standards requirement, ${ }^{18}$ which recognizes the practical need for executive discretion in implementation of the law.

The Court first gave the standards requirement both definition and force $^{19}$ with its decisions in Panama Refining Co. v. Ryan ${ }^{20}$ and A.L.A. Schechter Poultry Corp. v. United States, ${ }^{21}$ striking down two provisions of the National Industrial Recovery Act as unconstitutional delegations of legislative authority. In Panama Refining, the Court held that Congress must "perform its function in laying down policies and establishing standards, while leaving to selected instrumentalities the making of subordinate rules within prescribed limits and the determination of facts to which the policy as declared by the legislature is to apply."22 In Panama Refining and Schechter, the Court found the relevant NIRA provisions to lack adequate standards ${ }^{23}$ and to contain numerous policy objectives that were both broad and diverse. ${ }^{24}$ Subsequently, in Yakus $v$.

18. In Chadha, the Court apparently acknowledged this compromise in a footnote, but the text of the Court's opinion does not reflect such a recognition. In footnote 16 , the Court distinguished between legislative action and "quasi-legislative" activity by executive agencies on the ground that, although "some administrative agency action-rule making, for example-may resemble 'lawmaking' ... [t]hat kind of Executive action is always subject to check by the terms of the legislation that authorized it; and if that authority is exceeded it is open to judicial review . . . "462 U.S. at 953 n.16. This distinction necessarily recognizes that executive agencies do, with the Court's indulgence, make policy determinations. In fact, the Court cited 5 U.S.C. § 551(4) (1982), defining an agency rule as a "statement of general or particular applicability and future effect designed to implement, interpret, or prescribe law or policy ...."Id. Footnote 16, however, addresses a claim raised in a brief submitted by the House of Representatives, that striking down the legislative veto would sanction lawmaking by the Attorney General. Although the Court refuted this claim with a logic derived from the standards requirement, the crux of the Court's argument instead relied implicitly upon absolute nondelegation.

19. Before 1935, the Court's exposition of the standards requirement was imprecise. The Court approved the ascertainment of facts, Field v. Clark, 143 U.S. 649, 693 (1892) (upholding provision of Tariff Act of 1890 authorizing President to impose tariff on products of foreign country whose government subjected American goods to tariff that President deemed "reciprocally unequal and unreasonable"), or the filling in of details, United States v. Grimaud, 220 U.S. 506, 517 (1911) (upholding authorization of Secretary of Agriculture to promulgate regulations governing use of national forests), by the executive branch, when Congress had declared an "intelligible principle" to guide executive action, J.W. Hampton, Jr., \& Co. v. United States, 276 U.S. 394, 409 (1928); see also Buttfield v. Stranahan, 192 U.S. 470 (1904) (upholding grant of power to Secretary of Treasury to set minimum quality standard for imported tea). See generally Jaffe, An Essay on Delegation of Legislative Power: II, 47 Colum. L. Rev. 561, 566-69 (1947) (describing early cases in detail).

20. 293 U.S. 388 (1935) (invalidating $\$ 9$ (c) of National Industrial Recovery Act, Pub. L. No. 73-67, 48 Stat. 195, 200 (1935) (expired, as amended, 1936) [hereinafter cited as NIRA], which authorized President to prohibit interstate shipment of petroleum products produced or withdrawn from storage in violation of state law).

21. 295 U.S. 495 (1935) (invalidating $\$ 3$ of NIRA, which authorized President to promulgate codes of fair competition binding on all members of an industry).

22. 293 U.S. at 421.

23. Panama Refining, 293 U.S. at 430 ("Congress has declared no policy, has established no standard, has laid down no rule."); Schechter, 295 U.S. at 541 (Section 3 of NIRA "sets up no standards").

24. 293 U.S. at 418. 
United States, ${ }^{25}$ the Court prescribed criteria for evaluating legislative standards: Standards must be "sufficiently definite and precise"26 to enable a court "to ascertain whether the will of Congress has been obeyed."2z

Under the standards requirement, Congress retains responsibility for primary policy determination, the essential component of the legislative function. Congress may, however, delegate discretionary authority to administrators with more time and expertise to make detailed policy choices and prescribe subordinate rules. Executive policymaking merely implements the primary policy declared by Congress, and is thus subject derivatively to the checks of presentment and bicameralism. As Yakus makes clear, judicial review ensures derivative application of the constitutional checks by enforcing executive compliance with the statutory standards. Judicial review, moreover, serves in the context of executive policymaking a purpose analogous to one served by the presentment and bicameralism requirements for legislative lawmaking: to prevent lawmakers from arbitrary, unwise, or vindictive interference with the lives and property of individuals. ${ }^{28}$ The standards requirement thus represents a workable and constitutional compromise of the nondelegation principle. ${ }^{29}$

With its decision in Chadha, however, the Supreme Court abandoned its practical approach to the issue of delegation and adopted a line of rea-

25. 321 U.S. 414 (1944).

26. Id. at 426 .

27. Id. at 425 .

28. See The Federalist No. 73, at 442-43 (A. Hamilton) (C. Rossiter ed. 1961) (presentment requirement intended "to increase the chances in favor of the community against the passing of bad laws, through haste, inadvertence, or design"); 1 M. FARRAND, THE RECoRds of THE Federal CoNvention OF 1787, at 254 (1911) ("If the Legislative authority be not restrained, there can be neither liberty nor stability; and it can only be restrained by dividing it within itself, into distinct and independent branches."); see also The Pocket Veto Case, 279 U.S. 655, 678 (1929) (President's opportunity to study a bill before enactment is constitutional safeguard against "ill-considered and unwise legislation").

Judicial review of executive policymaking legitimates not only the delegation of power from Congress to executive agencies, but also from the people to Congress. The people arguably would be unwilling to delegate their power to Congress, knowing that Congress would redelegate to the executive branch, without the sort of due process protection provided by judicial review.

29. As the Chadha Court itself acknowledged, "[t]he bicameral process is not necessary as a check on the Executive's administration of the laws because his administrative activity cannot reach beyond the limits of the statute that created it," limits to be enforced by judicial review. 462 U.S. at 953 n.16 (citing Youngstown Sheet \& Tube Co. v. Sawyer, 343 U.S. 579, 585 (1952) (President's power to act must stem from either Constitution or act of Congress), and Ethyl Corp. v. EPA, 541 F.2d 1, 68 (D.C. Cir.) (en banc) (separate statement of Leventhal, J.), cert. denied, 426 U.S. 941 (1976) (courts have upheld delegations because judicial review ensures agencies exercise delegated power within statutory limits)). The presentment requirement is presumably also unnecessary as simply redundant in the context of action by executive agencies.

The Chadha Court also noted in footnote 16 that "Congress' authority to delegate portions of its power to administrative agencies provides no support for the argument that Congress can constitutionally control administration of the laws by way of a Congressional veto." 462 U.S. at 954 n.16. This Note argues, in contrast, that Congress' authority to delegate provides strong support for a restricted legislative veto. 
soning derived from the principle of absolute nondelegation. The Chadha opinion, in characterizing the legislative veto as an exercise of legislative power ${ }^{30}$ adopted a definition of legislative action which presumes absolute nondelegation. ${ }^{31}$ The Court cited as evidence of the veto's legislative character its alteration of the legal rights of persons outside the legislative branch, ${ }^{32}$ and its determination of policy. ${ }^{33}$ These characteristics, however, do not currently distinguish legislative from executive action; administrative agencies, acting pursuant to delegations of broad authority, routinely determine policy and alter legal rights. ${ }^{34}$ These characteristics can define legislative action only when the nondelegation principle is so strictly enforced that the executive must mechanically execute the law, without the exercise of discretion. The Court's definition thus rests upon a premise in direct conflict with that underlying the administrative state, which presumes that the executive may exercise discretion in implementing congressional policy.

Having used a presumption of nondelegation to classify the legislative veto as legislative action, the Court asserted that all exercises of legislative

30. The Court began with a presumption that the veto was an exercise of legislative power. 462 U.S. at 951 ("When any Branch acts, it is presumptively exercising the power the Constitution has delegated to it."). The Court then proceeded to identify the characteristics, described in text above, which in fact rendered the veto "legislative in purpose and effect." Id. at 952.

31. Commentators on the Chadha decision thus far have generally adopted either of two positions with regard to the Court's definition of legislative power. The first simply characterizes that definition as a nondefinition, due to its functional inadequacy. See, e.g., Strauss, Was There A Baby in the Bathwater? A Comment on the Supreme Court's Legislative Veto Decision, 1983 DUKE L.J. 789, 794-801; Tribe, The Legislative Veto Decision: A Law by Any Other Name?, 21 HaRv. J. ON Legis. 1, 9-10 (1984). The second holds that the definition is derived from an arbitrarily strict construction of the constitutional text. See, e.g., Smolla, Bring Back the Legislative Veto: A Proposal for a Constitutional Amendment, 37 ARK. L. Rev. 509, 515-16 (1983); Note, INS v. Chadha: The Future Demise of Legislative Delegation and the Need for a Constitutional Amendment, $11 \mathrm{~J}$. LEGIS. 317, 334-35 (1984). This Note, in contrast, recognizes the Court's definition as a definition, but one which rests upon a different premise-nondelegation-than does the modern administrative state. The use of nondelegation as a premise, moreover, supplies a rational basis for the Court's strict construction of article I.

Some critics have also drawn a connection between Chadha and the nondelegation doctrine, though generally on the basis of its result rather than its reasoning. The Chadha decision, by depriving Congress of a tool that greatly facilitates the delegation of legislative power, has the practical result of forcing Congress to cut back on such delegations. See, e.g., Tribe, supra, at 17; Note, supra, at 339-42. Richard Goldsmith has recognized the importance of absolute nondelegation to the Court's reasoning, noting that the assertion that lawmaking cannot occur outside the legislature was the "linchpin" of the Court's rationale. Goldsmith, INS v. Chadha and the Nondelegation Doctrine: $A$ Speculation, 35 Syracuse L. REv. 749, 756 (1984). Goldsmith simply argues, however, that the Court should not revive the nondelegation doctrine. Id. at 751-61. This Note proceeds beyond the point of recognizing the importance of the doctrine to the Court to argue that the Court misapplied the doctrine.

32. 462 U.S. at 952 .

33. Id. at 954 .

34. See, e.g., 47 U.S.C. $\S \S 307,309$ (1982) (Federal Communications Commission authorized to grant radio station licenses if "public convenience, interest, or necessity" will be served thereby); 49 U.S.C. $\S 45$ (1982) (Federal Trade Commission authorized to prohibit "unfair or deceptive" trade practices). 
power, including the veto, must satisfy the requirements of presentment and bicameralism. ${ }^{35}$ These requirements, the Court observed, serve three essential functions. Presentment protects the executive branch from intrusion by Congress, and protects the people from improvident laws; bicameralism assures that the legislative power is exercised only after opportunity for study and debate in two separate settings. ${ }^{36}$ Failure of the oneHouse legislative veto to comply with presentment and bicameralism left these concerns unmet and rendered the veto unconstitutional. ${ }^{37}$ This position, too, comports with the principle of strict nondelegation, which assumes that presentment and bicameralism are checks without which the people would not have entrusted lawmaking power to Congress.

The Chadha reasoning is thus inconsistent with the Court's historical approach to the issue of delegation, a conflict made especially significant by its context. The legislative veto has in the past facilitated standardless delegations of the legislative power; appropriately restricted, however, the veto could in fact complement enforcement of the standards requirement. Had the Court in Chadha acted in accord with its earlier requirement of standards rather than nondelegation, the outcome of Chadha could have been quite different.

\section{The Legislative Veto and the Standards Requirement}

The Court's limited application of the standards requirement ${ }^{38}$ led inexorably to a decline in the enactment of statutory standards. The princi-

35. The Court noted that the legislative veto did not qualify under any of the "four provisions in the Constitution, explicit and unambiguous, by which one House may act alone with the unreviewable force of law, not subject to the President's veto," including impeachment (House), art. I, § 2, cl. 5; trial following impeachment (Senate), art. I, § 3, cl. 6; review of presidential appointments (Senate), art. II, $\S 2$, cl. 2; and treaty ratification (Senate), art. II, $\S 2$, cl. 2.462 U.S. at 955-56.

36. 462 U.S. at 951 .

37. Id. at 959. In two summary affirmations, the Court extended the holding of Chadha to legislative vetos affecting rulemaking by executive and independent agencies. Process Gas Consumers Group v. Consumer Energy Council of America, 103 S. Ct. 3556 (1983), affg Consumer Energy Council of America v. FERC, 673 F.2d 425 (D.C. Cir. 1982); United States Senate v. FTC, 103 S. Ct. 3556 (1983), affg Consumers Union of U.S., Inc. v. FTC, 691 F.2d 575 (D.C. Cir. 1982) (per curiam).

38. In Kent v. Dulles, 357 U.S. 116 (1958), the Court struck down a regulation designating membership in the Communist Party as grounds for refusal of a passport. The Court declared the regulation unauthorized under a narrow interpretation of the Passport Act, reasoning that a broader interpretation would endanger individual liberties and might render the Act an unconstitutional delegation of legislative authority. Id. at 129. Justice Brennan, concurring in United States v. Robel, 389 U.S. 258, 275 (1967), observed that "[t]he area of permissible indefiniteness narrows . . . when the regulation invokes criminal sanctions and potentially affects fundamental rights . . . . This is because the numerous deficiencies connected with vague legislative directives . . . are far more serious when liberty and the exercise of fundamental rights are at stake."

The Court has also implied that Congress may not delegate its explicit constitutional power to tax. See National Cable Television Ass'n v. United States, 415 U.S. 336 (1974) (NCTA) and FPG v. New England Power Co., 415 U.S. 345 (1974), interpreting the Independent Offices Appropriation Act of 1952 to authorize the Federal Power Commission and the Federal Communications Commission, 
pal reason for the Court's lax enforcement of the standards requirement was apparently a recognition that meaningful standards are not feasible in every situation requiring Congress to delegate authority. As the Court acknowledged in American Power $\mathcal{E}$ Light Co. v. SEC, ${ }^{39}$ Congress cannot devise a standard for use in unforeseeable circumstances. ${ }^{40}$ Moreover, Congress may lack either the expertise or the institutional capacity to determine policy for even foreseeable circumstances. The number and complexity of issues facing the federal government preclude close and competent scrutiny by each individual member of Congress of every situation requiring discretionary agency action. ${ }^{41}$ Strict adherence to the standards requirement when standards could not be written would have frustrated the efficient operation of government. Accordingly, the Court opted to relax the standards requirement. ${ }^{42}$

The sharp increase since the 1930's in the use of the legislative veto exacerbated the problem of standardless delegations. ${ }^{43}$ As critics of the

respectively, to charge regulated companies only fees to cover specific services rendered. The Court suggested in NCTA, 415 U.S. at 340-41, that if the Act were read to authorize a tax on regulated companies, rather than a fee, the Act might constitute an invalid delegation of legislative authority.

Justice Harlan's dissent in Arizona v. California, 373 U.S. 546, 603 (1963), remained until 1980 the only argument by a member of the Supreme Court for general application of the standards requirement. A number of commentators, however, have urged a return to the requirement on a widespread basis. See, e.g., W. Douglas, Go East, Young MaN 217 (1974); J. Ely, Democracy and Distrust 131-34 (1980); J. Freedman, Crisis and Legrtimacy: The Administrative Process AND AMerican Government 78-94 (1978); T. Lowi, The END of Liberalism: The Second Republic of the United States 92-107, 300-01 (1979); Aranson, supra note 7; Gewirtz, The Courts, Congress and Executive Policy-Making: Notes on Three Doctrines, 40 LAw \& ConTEMP. PROBS., Summer 1976, at 46, 49-65.

39. 329 U.S. 90 (1946).

40. American Power upheld a vague delegation when it was "unreasonable and impracticable to compel Congress to prescribe detailed rules . . . ." 329 U.S. at 105; see also United States v. Southwestern Cable Co., 392 U.S. 157 (1968) (upholding FCC regulation of cable television under Communications Act of 1934, even though Congress of 1934 could not have foreseen development of cable television).

41. See Davis, A New Approach to Delegation, 36 U. GHI. L. Rev. 713, 722 (1969).

42. But see J. ELY, supra note 38, at 132-33 (arguing that nondelegation doctrine suffered "death by association" with substantive due process and restrictive interpretation of commerce power); Aranson, supra note 7, at 16 (suggesting that Court found other legal doctrines, such as procedural due process and equal protection, better suited than nondelegation doctrine to control "legislatively authorized executive excesses").

43. Since the first legislative veto appeared in 1934, Legislative Appropriations for Fiscal Year 1933, Pub. L. No. 72-212, § 407, 47 Stat. 382, 414-15 (1932) (expired 1935), legal scholars and the federal courts have debated the veto's constitutionality. For commentary in opposition to the legislative veto, see J. Bolton, The Legislattve Veto: Unseparating the Powers (1977); Bruff \& Gellhorn, Congressional Control of Administrative Regulation: A Study of Legislative Vetoes, 90 HARv. L. Rev. 1369 (1977); Dixon, The Congressional Veto and Separation of Powers: The Executive on a Leash?, 56 N.C.L. REv. 423 (1978); Ginnane, The Control of Federal Administration by Congressional Resolutions and Committees, 66 HARv. L. REv. 569 (1953); Henry, The Legislative Veto: In Search of Constitutional Limits, 16 HARv. J. ON LEGIS. 735 (1979); Martin, The Legislative Veto and the Responsible Exercise of Congressional Power, 68 VA. L. Rev. 253 (1982); Scalia, The Legislative Veto: A False Remedy for System Overload, 3 Regulation, Nov.-Dec. 1979, at 19; Watson, Congress Steps Out: A Look at Congressional Control of the Executive, 63 CALIF. L. REv. 983 (1975). 
veto correctly charged, Congress employed the veto mechanism more often than not for purposes antithetical to the standards requirement. ${ }^{44}$ Congress often found it politically convenient to entrust the determination of general policy to agency officials not directly accountable to the voters, rather than to risk making a controversial policy choice itself. ${ }^{45}$ Similarly, the veto most likely relieved Congress of the need to expend the time and effort required to achieve a compromise when policymaking would have been internally divisive. The legislative veto facilitated avoidance of difficult policy choices by permitting Congress to preempt any agency policy choice that it found politically unacceptable.

The objective apparently underlying the Chadha decision was to check the proliferation of broad congressional delegations of discretionary authority. The Court's concern is evident first in the Court's premise that Congress may not delegate legislative authority to another branch of government. Also, by invalidating the legislative veto, the Court deprived Congress of a significant control over administrators' policy decisions, a result which should make Congress less willing to delegate. Finally, as a number of commentators have noted, ${ }^{46}$ the Chadha result is consistent with recent arguments by Justice Rehnquist for a revival of the standards requirement. ${ }^{47}$ Although these arguments did not persuade a majority of the Court, the Chadha result indicates a commitment to nondelegation much greater than the lack of support for Justice Rehnquist's position suggests.

The legislative veto could also, however, complement and thereby rein-

For commentary in support of the legislative veto, see Abourezk, The Congressional Veto: A Contemporary Response to Executive Encroachment on Legislative Prerogatives, 52 IND. L.J. 323 (1977); Cooper \& Cooper, supra note 8; Dry, The Congressional Veto and the Constitutional Separation of Powers, in The PResidency IN THE Constirutional Order 195 (1981) (J. Bessette \& J. Tulis eds.); Javits \& Klein, supra note 8; Miller \& Knapp, The Congressional Veto: Preserving the Constitutional Framework, 52 IND. L.J. 367 (1977); Schwartz, The Legislative Veto and the Constitution-A Reexamination, 46 GEo. WASH. L. REv. 351 (1978); Stewart, Constitutionality of the Legislative Veto, 13 HARv. J. ON LEGIS. 593 (1976).

44. See, e.g., Bruff \& Gellhorn, supra note 43, at 1381-1409, 1426-28 (in five case studies of regulatory rulemaking, Congress left key issues unresolved in authorizing statutes and relied on legislative veto mechanism to maintain control over agency policy initiatives); Martin, supra note 43, at 268-71 (rather than make difficult policy choice on duty of local transit authorities to accommodate the disabled, Congress delegated decision to Department of Transportation, subject to Congressional veto of unpopular regulations).

45. See J. ELY, supra note 38, at 133 (quoting Stewart, The Reformation of American Administrative Law, 88 HARv. L. Rev. 1669, 1695 (1975)); Martin, supra note 43, at 267-74. Alternatively, Congress may be driven by mere laziness or by preoccupation with more pressing concerns.

46. See, e.g., Goldsmith, supra note 31, at 754-55; Rabin, An Overview of the Chadha Case, 35 SYRACUSE L. REv. 703, 712 (1984); Note, supra note 31, at 340-41.

47. See Industrial Union Dept. v. American Petroleum Inst., 448 U.S. 607, 686-87 (1980) (Rehnquist, J., concurring) (arguing that Court should "reshoulder the burden of ensuring that Congress itself make the critical policy decisions"); American Textile Mfrs. Inst. v. Donovan, 452 U.S. 490, 547 (1981) (Rehnquist, J., dissenting) (Congress may not "simply abdicate[ ] its responsibility for the making of a fundamental and most difficult policy choice"). 
force the standards requirement by providing an alternative for situations in which standards are not feasible. For example, when an agency had to cope with unstable or unforeseeable circumstances, Congress could identify a general objective and, through the veto mechanism, review particularized policy decisions made by the agency. Similarly, when Congress lacked sufficient time or expertise, it could entrust detailed policymaking to more expert agency staffs, reserving the power to veto agency proposals that conflicted with a stated general objective. The, veto thus could serve the purpose of the standards requirement by enabling Congress to retain final control of subordinate policymaking where such control ex ante is impossible. ${ }^{48}$

\section{Defining a Restricted Legrslative Veto}

Congressional abuse of the legislative veto to facilitate avoidance of difficult policy decisions has detracted from otherwise strong arguments that the veto could advance the goal of congressional responsibility underlying the standards requirement. Rather than discrediting these arguments entirely, ${ }^{48}$ however, such abuse implies at most a need for restrictions on the exercise of the legislative veto. Such restrictions should serve two functions. First, they should ensure that the veto furthers the goal of the standards requirement. Specifically, the veto should be neither so available nor so structured as to encourage congressional avoidance of all policy determination at the time of delegating authority. Second, availability of the veto should be sufficiently restricted so that failure of the veto to comply with presentment and bicameralism would be for practical, if not theoretical, purposes insignificant, or at least in line with other instances in which the Court has already indicated that compliance is not necessary. The checks of presentment and bicameralism are explicit concerns of the Chadha opinion, but are also present implicitly in the standards requirement.

\section{A. Elimination of the Negative-Form Veto}

The first objective of encouraging congressional policymaking could be achieved in part by eliminating the negative-form legislative veto. Prior to Chadha, a substantial majority of veto provisions took the negative form, ${ }^{80}$

48. See Abourezk, supra note 43, at 330-35; Cooper \& Cooper, supra note 8, at 511; Miller \& Knapp, supra note 43 , at $376-77$.

49. See, e.g., Bruff \& Gellhorn, supra note 43, at 1439 (arguing that disadvantages of legislative veto cannot be ameliorated and require Congress to abandon veto); Martin, supra note 43, at 301-02 (same).

50. Of the 85 legislative veto provisions listed in Appendix 1 to Justice White's dissent in Chadha, 462 U.S. at $1003-13,71$, or $84 \%$, are written in the negative form. 
whereby agency action pursuant to a grant of discretionary authority took effect after a specified time unless Congress passed a resolution of disapproval. ${ }^{51}$ This structure relieved Congress of the need to articulate policy when delegating authority, as Congress could easily veto agency proposals after passage of the enabling legislation.

Similarly, the decision either to exercise the veto or not, represented under the negative veto provision by action or inaction respectively, did not require Congress to articulate policy. The veto resolution itself was merely a negative reaction to an agency proposal, rather than an affirmative statement of congressional policy. Disapproval could be for any of a number of unstated reasons, and the legislative history typically provided few clues to Congress' actual motivation. ${ }^{22}$ Similarly, inaction by Congress, representing tacit approval of an agency proposal, neither required nor encouraged Congress to indicate its policy preferences. As a result, the legislative veto in its negative form was a poor substitute for statutory policymaking.

The legislative veto in its affirmative form, by contrast, could encourage Congress to articulate a general policy when delegating discretionary authority. Under an affirmative veto provision, agency action would take effect after a specified time period only if Congress passed a resolution of approval. In practical terms, however, Congress simply lacks the time necessary for review and approval of every agency action. Demands for efficiency in congressional operations would thus require the prescription of policy guidelines for an agency to follow in most circumstances. The affirmative veto provision, moreover, would be more flexible than an unconditional delegation of authority, even one accompanied by policy instructions. As indicated earlier, ${ }^{53}$ a primary reason for the demise of the standards requirement has been the impracticality of requiring Congress to predict all circumstances in which standards and policies must be applied. The affirmative veto would permit a requirement of general policy prescriptions, while providing a safety valve for situations in which such general prescriptions were inappropriate. In short, the structure of the affirmative legislative veto, together with practical restrictions on its availability, would advance the goal of the standards requirement when enforcement of the requirement would be impossible or unwise. ${ }^{54}$

51. See supra note 11 and accompanying text.

52. See Bruff \& Gellhorn, supra note 43, at 1417 (floor votes of an entire House on merits of veto resolution infrequent); Martin, supra note 43, at 274-77 (legislative history of legislative veto usually less effective and less reliable indicator of congressional intent than legislative history of statute).

53. See supra text accompanying notes 38-40.

54. Professor Kenneth Davis has argued that the purpose of the nondelegation doctrine is to guard against unnecessary and uncontrolled discretionary power, and that this purpose is best served by judicial attention to the totality of protections against arbitrariness, including both procedural safe- 


\section{B. The Constitutionality of an Affirmative Legislative Veto}

Even under the affirmative form of the legislative veto, neither a veto nor its complement, a resolution approving agency action, would be in direct compliance with presentment and bicameralism. ${ }^{55}$ The veto, however, could be designed to comply derivatively with those requirements, and the approval resolution could be so restricted that its failure to comply would be practically, if not theoretically, insignificant.

guards and standards. Davis would require administrative agencies to create and articulate internal standards to govern their policy judgments and preclude arbitrariness; in the absence of such internal standards, agency action would be invalid. K. Davis, ADMinistrative Law Treatise $\S 3: 15$, at 206-16 (2d ed. 1978). Davis' substitution of agency standards for legislative standards is a second-best solution, however, to the problem of congressional avoidance of policy determination. Davis would permit such avoidance as long as agency policymaking were sufficiently self-circumscribed.

55. Critics of the legislative veto maintain that it: (a) violated the presentment clause by denying the President the opportunity to exercise his veto power, see, e.g., Dixon, supra note 43, at 440; Henry, supra note 43, at 749-51; Martin, supra note 43, at 295-300; (b) involved Congress too deeply in agency administration of the law, thereby infringing upon the constitutional duty of the President faithfully to execute the law, see, e.g., Henry, supra note 43, at 756-60; Scalia, supra note 43, at 21; (c) unconstitutionally arrogated to Congress the power of judicial review, see, e.g., Bruff \& Gellhorn, supra note 43, at 1429-33; Dixon, supra note 43, at 442-45; and (d) violated, in its oneHouse form, the requirement of bicameralism, see, e.g., Dixon, supra note 43, at 441; Henry, supra note 43 , at 748-51; Martin, supra note 43 , at 295-300.

Supporters of the legislative veto contend that: (a) the presentment requirement was satisfied when the President signed the original legislation containing a legislative veto provision, or when such legislation was passed over his veto, see, e.g., Abourezk, supra note 43, at 338-39; Stewart, supra note 43, at 614 ; (b) the legislative veto was constitutional under the necessary and proper clause, which allows Congress to constrain grants of both quasi-legislative and quasi-judicial power to the executive branch, see, e.g., Javits \& Klein, supra note 8, at 473; Miller \& Knapp, supra note 43, at 382-83; (c) the bicameralism requirement was satisfied when both Houses enacted legislation containing a one-House veto provision, see, e.g., Abourezk, supra note 43, at 341; Dry, supra note 43, at 211; and (d) Congress has the right to make conditional delegations of authority, reserving partial authority to itself, see, e.g., Cooper \& Cooper, supra note 8, at 473-76; Javits \& Klein, supra note 8, at 473.

The federal courts, too, have participated in this debate. The U.S. Court of Claims, in Atkins v. United States, 556 F.2d 1028 (C.t. Gl. 1977), cert. denied, 434 U.S. 1009 (1978), upheld the oneHouse veto provision of the Federal Judicial Salary Act of 1967 as "a device authorized by article I, section 1, coupled with the necessary and proper clause." Id. at 1070-71. The Court noted that the veto "contravenes neither the broad principle of the separation of powers nor any specific provision of the Constitution." Id. at 1071.

The Court of Appeals for the D.C. Circuit, in Consumer Energy Council of America v. FERC, 673 F.2d 425 (D.C. Cir. 1982), affd sub nom. Process Gas Consumers Group v. Consumer Energy Council of America, 103 S. Ct. 3556 (1983), held the one-House veto provision of the Natural Gas Policy Act of 1978 to be an unconstitutional violation of both the presentment and bicameralism requirements. Relying on $F E R C$, the same court subsequently struck down the one-House veto provision of the Federal Trade Commission Improvements Act, in Consumers Union of U.S., Inc. v. FTC, 691 F.2d 575 (D.C. Cir. 1982) (per curiam), affd sub nom. United States Senate v. FTC, 103 S. Ct. 3556 (1983).

In Buckley v. Valeo, 424 U.S. 1, 140 n.176 (1976), the Supreme Court dismissed as not ripe for decision a challenge to the one-House veto provision of the Federal Election Campaign Act Amendments of 1974, 2 U.S.C. $\$ 438$ (d)(2) (1982), when the veto had not yet been exercised. Justice White dissented to this dismissal, however, noting that he would have upheld the veto provision as constitutional. Id. at 285-86. 


\section{Denial of Exceptions to Statutory Policy}

Under the affirmative form of the legislative veto, actual veto of an agency proposal would take the form of congressional inaction-in other words, failure to approve. Such a veto, lacking any substantive manifestation, could not be subject as a practical matter to the requirements of presentment and bicameralism; yet the veto would represent a definite policy choice which, if given effect by positive action, would in theory be subject to those requirements. That policy choice, however, would simply be the policy previously authorized by the enabling legislation. More specifically, if the enabling legislation were to forbid an agency to deviate from a given policy without congressional approval, congressional failure to approve a deviation would merely reaffirm that policy. That policy choice, being contained in legislation passed by both Houses and submitted to the President, would have been previously subject to and in compliance with the constitutional requirements. The legislative veto, therefore, could be said to comply derivatively, if not directly, with those requirements. As described above, ${ }^{58}$ the Court sustained such a derivative satisfaction of presentment and bicameralism when it devised the standards requirement.

\section{Approval of Exceptions to Statutory Policy}

Congressional approval of agency action, on the other hand, would present a problem requiring more than an analytical solution. Approval would take the form of an affirmative resolution, potentially representing an entirely new policy choice complying neither directly nor indirectly with the requirements of presentment and bicameralism. If the approval resolution could be limited, however, to a grant of an exception from the policy declared in the enabling legislation, then waiver of the constitutional requirements would comport with the Court's history of allowing similar waivers under the necessary and proper clause, when noncompliance was required by circumstance and limited in frequency.

The necessary and proper clause ${ }^{57}$ confers upon Congress the power to make all laws necessary and proper for carrying into execution all powers vested in the government. Congress is not limited under the clause to such measures as are indispensable to effectuating its express constitutional powers. Instead, a congressional act is constitutional under the clause when the desired end is legitimate and within the scope of the Constitution, and when the chosen means is appropriate, plainly adapted to the

56. See supra text accompanying notes 28-29.

57. U.S. CoNST. art. I, § 8, cl. 18. 
end, and consistent with the letter and spirit of the Constitution. ${ }^{88}$ In $\mathrm{Mc}$ Grain v. Daugherty, ${ }^{50}$ the Court found the congressional subpoena to be authorized under the clause. Congress issues a subpoena in the form of a one-House resolution, which clearly avoids presentment and bicameralism. Nevertheless, as the Gourt observed in McGrain, "[a] legislative body cannot legislate wisely or effectively in the absence of information ... and where the legislative body does not itself possess the requisite information . . . some means of compulsion are essential to obtain what is needed." 60 The Court therefore upheld the congressional subpoena as "a necessary and appropriate attribute of the power to legislate," the subpoena's failure to comply with the constitutional requirements for legislation.

In Humphrey's Executor v. United States, ${ }^{62}$ the Court permitted a congressional committee, when previously authorized by statute, to require by means of resolution that an administrative agency conduct an internal investigation. Humphrey's Executor gains special significance from its context: a direct intrusion by Congress into the operations of the executive branch. Despite such intrusion, the Court determined that neither constitutional check was relevant to Congress' performance of this particular legislative function-again the discovery of information without which Congress would be unable or unwilling to legislate. The Court simply declined, implicitly, to classify the demand for investigation, or the congressional subpoena, as "legislation" for which compliance is of constitutional necessity.

An approval resolution restricted to a grant of an exception from a statutory policy would help to ensure that Congress did not act without adequate information and would thereby facilitate consistent enforcement of the standards requirement. When Congress lacks necessary information by virtue of its simple inability to predict the future, it is often unwilling to prescribe a fixed and comprehensive policy. The restricted approval resolution would allow Congress to prescribe a policy according to information available at the time of legislation, but to make exceptions to that policy as the passage of time yielded further information.

Admittedly, the restricted affirmative veto would involve a different sequence of events than do the congressional subpoena and the order to investigate. The latter operate before the passage of legislation, while the veto would operate afterwards. There would be a difference also in practi-

58. M'Culloch v. Maryland, 17 U.S. 316, 421 (1319).

59. 273 U.S. 135 (1927).

60. Id. at 175.

61. Id.

62. 295 U.S. 602 (1935). 
cal effect. The veto or the resolution of approval would forbid or permit some substantive action by an agency, while the subpoena and investigation order require only the provision of information.

These differences, however, would not rise to constitutional significance, for they would not render the affirmative veto's noncompliance with presentment and bicameralism more dangerous than that of the other devices. If anything, the potential dangers raised by the affirmative veto would be less significant. As the veto itself would merely reaffirm a policy of its enabling legislation, it would create no new interference with the executive branch and no new danger of an improvident law. A resolution approving an exception from stated policy would create no new interference with the actions of executive agencies, for the resolution would simply approve a request of the executive branch. ${ }^{63}$ The approval resolution, moreover, would preclude improvident application of the enabling legislation to situations for which it was not designed.

\section{Additional Restrictions on the Affirmative Veto: New Information and Judicial Review}

Limitation of approvals to necessary exceptions might occur as a matter of course, were the standards requirement to be enforced. It would be extremely inefficient for Congress, having spent the time necessary to agree upon and articulate a policy, to devote considerably more time after passage of the enabling legislation to approving frequent deviations from that policy. External restrictions should nonetheless be imposed to provide more certainty.

\section{New Information}

The first such restriction should be a requirement that an agency articulate the particular circumstances or new information justifying an exception from the previously enacted policy. This restriction would confine the agency request to an exception rather than a change in policy. Congress would be required, in turn, to approve an agency request without amend-

63. Resolutions approving policy proposals of independent agencies are less problematic in terms of the separation of powers than those approving executive proposals. Officials of independent agencies are not subject to the presidential removal power, Humphrey's Executor v. United States, 295 U.S. 602 (1935); moreover, "independent agencies are often free, at least in a formal sense, of other relationships with the White House that characterize the executive-branch agencies," Strauss, The Place of Agencies in Government: Separation of Powers and the Fourth Branch, 84 Colum. L. REv. 573,589 (1984), including centralized oversight of rulemaking and the obligation to clear legislative matters with the Office of Management and Budget, id. at 590. Because independence removes an agency from much direct executive branch control, presidential disagreement with a policy exception requested by an independent agency and approved by Congress does not pose a problem of undue interference with executive prerogative. 
ment. Such a restriction would, at least in theory, preclude Congress from using the approval mechanism to effect a policy shift.

A hypothetical revision of the legislative veto provision contained in the International Development and Food Assistance Act of $1975^{84}$ can serve to illustrate this requirement. The Act now authorizes a general distribution of foreign aid but provides for a two-House veto of aid to governments engaged in "a consistent pattern of gross violations of internationally recognized human rights ...." The Act then lists a number of practices representing such violations. Rewritten in the affirmative form, the Act would forbid distribution of aid to foreign governments engaged in these violations, but provide for limited approval of aid to such governments when justified by circumstance. Such a statute would set forth clearly the policy to be followed in most instances and in the absence of action by Congress. The executive could, however, request an exception to this policy by stating its justification in a particular instance. For example, the President might decide that aid to a foreign government with a record of human rights violations was nevertheless necessary to prevent an economic collapse. Congress could permit such aid by passing a resolution of approval. Congress would have to enact legislation, however, to impose additional restrictions on the provision of aid.

\section{Judicial Review}

The requirement that an agency delineate the specific circumstances justifying an exception, however, would by itself be insufficient; judicial review would be necessary as a supplemental restriction for several reasons. First, judicial review could ensure compliance with the approval procedure. The courts could ensure that an agency did not grant itself an exception by violating a statute without congressional approval, and, more importantly, that Congress granted exceptions without amendment and only when properly requested.

Additionally, judicial review could ensure that a resolution of approval permitted only a genuine exception to policy, not a disguised policy shift. In testing the justifications offered by an agency, courts would ask such

64. 22 U.S.C. $§ 2151 \mathrm{n}(1982)$.

65. 22 U.S.C. $\$ 2151$ n(a) (1982) provides that:

No assistance may be provided . . . to the government of any country which engages in a consistent pattern of gross violations of internationally recognized human rights, including torture or cruel, inhuman, or degrading treatment or punishment, prolonged detention without charges, causing the disappearance of persons by the abduction and clandestine detention of those persons, or other flagrant denial of the right to life, liberty, and the security of person, unless such assistance will directly benefit the needy people in such country.

Congress thus may veto foreign aid to a government whose human rights violations outweigh the importance of any benefit to needy people of that country. 
questions as these: Does the circumstance offered as justification actually exist? Is the circumstance merely a one-time occurrence, or is it likely to recur and thus necessitate further exceptions? Is the exception significant relative to the size of the relevant program as a whole (in terms of cost, duration, or other appropriate measure)? Courts would evaluate an exception without inquiring whether Congress actually granted the exception for the reason offered by the executive, or, rather, for political or other reasons. An exception would be required to withstand scrutiny on its own.

Finally, judicial review could ensure that a subtle shift in policy did not occur by means of a pattern of congressional resolutions approving individual exceptions to a stated policy-exceptions which, taken together, represented a consistent failure to apply that policy in favor of another policy, not yet articulated in legislation. In most instances, presumably, exceptions under any given statute would be unrelated, stemming from circumstances or information of specific, but not general relevance. When such circumstances or information required a pattern of exceptions, however, congressional approval would be held invalid. Congress would be required to amend the enabling legislation to provide a policy capable of more consistent application. ${ }^{68}$

An illustration of the effect of such judicial review can be drawn from the Energy Security Act, ${ }^{67}$ which currently authorizes either House to veto contract renegotiations by the Synthetic Fuels Corporation (SFG) that exceed $175 \%$ of initial cost estimates. Rewritten in the affirmative form, the Act would forbid the SFC to renegotiate contracts for amounts greater than the $175 \%$ limit without securing from Congress an approval resolution. Congress would be able to permit an exception from the $175 \%$ limit if, for instance, a synthetic fuels producer needed to replace existing equipment on a one-time basis to comply with a new requirement of the Environmental Protection Agency. If more expensive contracts were nec-

66. The federal courts already have considerable experience with this type of judicial review in the determination of consistent patterns or practices in statutory application. In anti-discrimination law, for example, the discriminatory intent branch of equal protection analysis often requires courts to infer purposeful discrimination on the part of government officials from patterns emerging from official action. As Justice Powell, writing for the majority in Arlington Heights v. Metropolitan Housing Development Corp., 429 U.S. 252 (1977), described: "The impact of the official action . . . may provide an important starting point [in determining the existence of a discriminatory purpose]. Sometimes a clear pattern, unexplainable on grounds other than race, emerges from the effect of the state action even when the governing legislation appears neutral on its face." Id. at 266. As Justice Powell noted, the pattern need not be extreme to be detected and held unlawful, although without a clear pattern, a finding of intent must be informed by such other evidentiary sources as historical background and legislative history. Id. at 266 n.13, 267-68. Despite obvious substantive differences, judicial experience with this means of detecting the policies which underlie official action can inform judicial review of approval resolutions for possible manifestations of underlying policy shifts.

67. 42 U.S.C. $\S \S 8724,8741$ (d) (1982). 
essary, however, to permit a substantial number of fuel producers to comply with that requirement, or if additional exceptions were necessary within a given time period for other reasons, such as severe inflation, ${ }^{68}$ Congress would be required to amend the Act. Such patterns of exception would indicate that Congress was willing to exceed the specified limit, and thus vary from the expressed policy, on more than an exceptional basis.

\section{ConCLusion}

A legislative veto written in the affirmative form and restricted to approval or denial of exceptions from a statutory policy would further the responsible exercise of legislative power by accommodating imperfections in Congress' inability to predict the future. Exercise of the veto, as well as passage of an approval resolution, would present dangers of no greater constitutional significance than do other congressional actions for which the Court has declined to require presentment and bicameralism.

Under the reasoning of this Note, the result in Chadha, viewed separately from the Court's analysis, was both right and wrong. The Court was correct in striking down a legislative veto provision written in the negative form. Had the veto been written in the affirmative form, however, the case need never have been litigated. Written affirmatively, the Immigration and Nationality Act would have provided that the INS could suspend deportation of any alien satisfying the specified criteria; the INS could not, however, suspend deportation of any alien failing to satisfy these requirements unless Congress passed a resolution of approval. If such had been the language of the Act, the INS, having decided that Chadha satisfied the necessary criteria, could have suspended his deportation without consulting Congress. Congress would have had to enact new legislation to revoke this suspension.

The Court in Chadha simply went too far by treating all legislative veto provisions as though they were alike in both form and intent. The Court should instead have been more circumspect in its analysis, as well as more attentive to its own historical compromises with respect to both the nondelegation principle and the requirements of article I. Had the Court approached the legislative veto from the perspective of the standards

68. Courts could determine the existence of a congressional pattern or practice of related exceptions in two ways: (1) by determining the ratio of exceptions granted to actions taken by the agency pursuant to the stated policy; and (2) by examining the number of exceptions granted within a given time period (e.g., whereas five exceptions granted in a twenty-year period probably would not represent a significant pattern, five exceptions within one or two years probably would). The choice of appropriate limiting ratios of exceptions per agency action and exceptions per time period would of necessity be somewhat arbitrary, governed by judicial discretion and the particular circumstances of the case. 
Legislative Veto

requirement, it could have addressed abuse of the veto and restricted its use, rather than rejecting the mechanism entirely.

-Emily S. McMahon 